\title{
Study of the technical performance of localized irrigation and its environmental and agro- economic impact in the first areas of collective reconversion at the irrigated perimeter of the Tadla - Beni Moussa perimeter of the west - Morocco
}

\author{
ABDELLAH MOURADI ${ }^{1 *}$, ZEHOR AIT YACINE ${ }^{2}$, ABDERRAZAK EL HARTI $^{3}$ \\ 1 PhD student FST/ Sultan Moulay Slimane University, Beni Mellal, Morocco \\ 2 Professor at FST/ Sultan Moulay Slimane University, Beni Mellal, Morocco \\ 3 Professor at FST/ Sultan Moulay Slimane University, Beni Mellal, Morocco
}

\begin{abstract}
The evaluation of the performance of the localized irrigation system involved a selected sample of farmers to reflect the diversity of the study area. The hydraulic diagnosis revealed the absence of apparent malfunctioning anomalies of the installations studied (Coefficient of Distribution Uniformity $\geq 90 \%$ with average application efficiencies and overall of 90.54 and $86.83 \%$ respectively). In terms of the combined use of surface and underground irrigation water this new technique has saved about $30 \%$ compared to conventional irrigation. The agro-economic evaluation revealed that the crops practiced have high value-added and optimize the value of irrigation water. The environmental impact has resulted in an average drawdown of the static level of groundwater of $2.59 \mathrm{~m}$ due mainly to the new irrigation method introduced, which limited the percolation of water to the aquifer. The drip-to-drip transition resulted in an increase in salinity relative compared to the reference situation $(+0.59 \%$, or $0.01 \mathrm{mS} / \mathrm{cm})$ but to different degrees depending on the prospecting soil horizon. The practice of fertilization remains the major and probable cause of soil salinization of aquifers. The effect of soluble salts on the soil was investigated through the risks associated with sodium, which showed that the soil permeability problem does not arise at this time $(\mathrm{SAR} \leq 15)$. The residual sodium carbonate remains less than $1.25 \mathrm{meq} / 1$ thus not causing soil dispersion.
\end{abstract}

Keywords: Transition, localized irrigation, Collective conversion, water saving, valorization of Irrigation water, environmental impact, efficiency, Uniformity distribution, Tadla perimeter.

\footnotetext{
${ }^{*}$ Corresponding author: mouradi_abdellah@yahoo.fr
} 


\section{1 - INTRODUCTION}

In the context of the scarcity of water, the agricultural sector mobilizing more than $80 \%$ of water resources (Belghiti 2012) is called to use irrigation water wisely through a better technical, economic and social valuation. of this resource, and especially to preserve it for future generations (Moghli, E., Benjelloun, T., 2000). The organization of agricultural users around collective irrigation projects aimed at reconversion to localized irrigation represents a promising solution to deal with this new situation (Dionnet M. et al 2006). In the wake of these reconversion processes, Vidal et al. 2001 cited by Dionnet M. et al 2006 indicated that if the conditions for implementing such techniques are not met, particularly in terms of support for new users, reconversions in localized irrigation can lead to disappointing agronomic performance. For this purpose, the post-project evaluation of the technical performance of installations is a tool for detecting whether the practices of agricultural users are in line with good practice, namely ecological intensification, the use of scarce resources and the increase in productivity and added value.

\section{2 - MATERIAL AND METHODS}

To achieve the objectives assigned to this work, a methodological progression has been adopted. To do this, a representative sample of 32 farms was chosen to undertake this investigation. Data collection and information was based on interviews with irrigators on various aspects of exploitation, resource use and productivity. Field visits were made to measure certain technical performance parameters in situ, in this case the technical efficiencies and uniformity of watering of the facilities. The environmental impact was addressed through the analysis of environmental parameters from the ORMVAT analysis laboratory. The material used consists of volumetric water meters of the block plug, manometers, graduated test tubes, chronometers, auger, precision balance and an oven. The analysis of the survey sheets, the production of graphs and the processing of the data were carried out on a Microsoft Office Excel spreadsheet (version 2016) with the use of all its statistical processing functions (calculation of mean, standard deviation standard and coefficient of variation). Some schematics have been done using the Auto CAD version 2009 software.

\section{3 - RESULTS AND DISCUSSIONS}

\section{3-1 HYDRAULIC DIAGNOSTICS}

\section{3-1-1 QUALITY OF SURFACE IRRIGATION WATER}

By analyzing the April 2016 data from the ORMVAT analysis laboratory related to the ionic balance of surface irrigation water and taking into account the guidelines for assessing the physicochemical quality of water from irrigation, it has been shown that this water is classified in the category requiring no restriction for its use in crop irrigation (low salinity: $0.51 \mathrm{mmhos} / \mathrm{cm}$, ie $326.4 \mathrm{mg} / 1$, remaining below the threshold of $1500 \mathrm{mg} / 1$ advanced by Phocaides A., 2008, moderately basic $\mathrm{pH}$ found in the normal range of water suitable for irrigation "6.5 to 8.4, Phocaides A., 2008", the risk of soil sealing is zero due to low salinity and the Sodium Adsorption Rate (SAR: 1.1) below the threshold of 15 (Phocaides A., 2008) The ions that may present risks of toxicity namely $\mathrm{Na}^{+}$and $\mathrm{Cl}^{+}$are in normal ranges (less than $10 \mathrm{meq} /$ 1, Phocaides A., 2008. The Nitrate content is very low (0.1 meq / 1 i.e $6.1 \mathrm{mg} / 1$, remaining below the $10 \mathrm{mg} / 1$ threshold, Labomag, 2012).

\section{3-1-2 TEST OF THE UNIFORMITY OF THE DISTRIBUTION OF IRRIGATION WATER}

According to Benouniche et al, 2014, the Distribution Uniformity Coefficient (CU) represents the ability of the facility to provide the same irrigation dose to an entire plot. At 
more than $90 \%$, uniformity is considered excellent; the lower it is, the more there are problems of distribution (clogging of the drippers for example). The study of the homogeneity of the water distribution at the irrigation station was based on the uniformity test and the uniformity coefficient proposed by Keller J. and Karmeli D. 1974. This Coefficient is defined as follows:

$$
\mathrm{CU}(\%)=\left(\mathbf{q}_{25} / \mathbf{q}-\right) * \mathbf{1 0 0}
$$

With: $\mathrm{q}_{25}=\Sigma \mathrm{qi} / \mathrm{4}(\mathrm{i}=1$ to 4$)$ : Average flow rate of the lower quartile (4 lower values in $1 / \mathrm{h}$ ) $\mathrm{q}^{-}=\Sigma \mathrm{qi} / 16$ (i=1 to 16$)$ : average flow $(\mathrm{l} / \mathrm{h})$ of the 16 measured drippers.

The uniformity test consists of the measurement of the flow rate for a sample of 16 drippers uniformly distributed over the sector and on the irrigation $\operatorname{ramp}\left(\mathrm{R}_{0}, \mathrm{R}_{1 / 4}, \mathrm{R}_{1 / 2}, \mathrm{R}_{1}\right)$ as illustrated on the diagram. experimental set-up below (Cemagref, 2003 cited by A .El Amri A. et al., 2012) following the protocol described in FAO bulletin 36 (Vermeiren L. 1983).

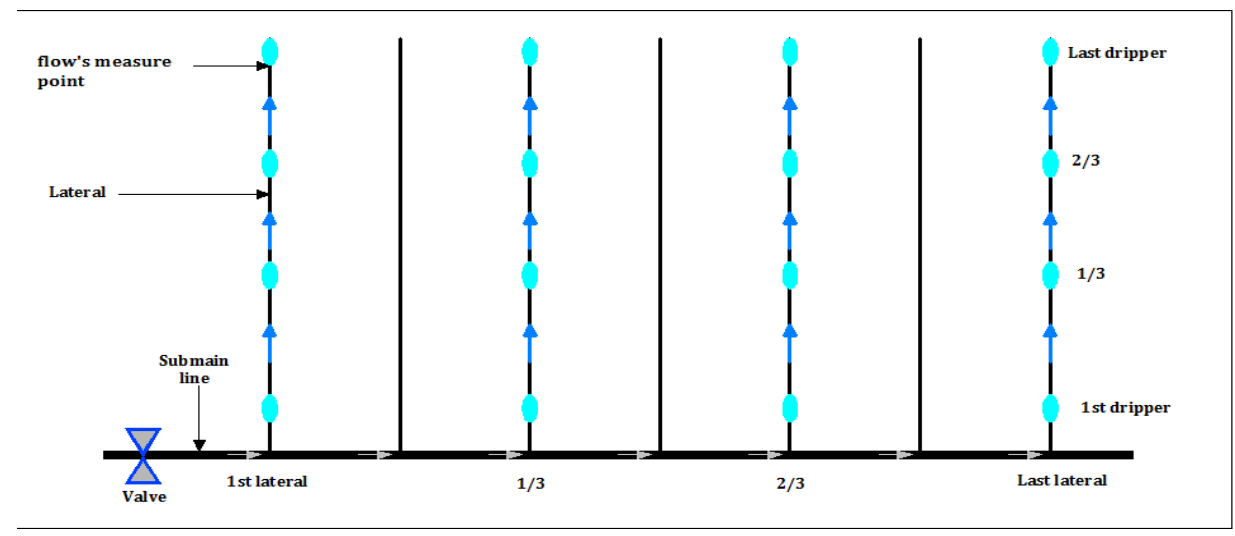

Fig 1: Experimental device of measurement points

The results obtained with regard to the uniformity of the distribution of irrigation water are very promising oscillating between $90 \%$ and $98 \%$ with an average of $96 \%$ and a small inter-farm variation ( $\mathrm{CV}$ of $2.12 \%$ ). Referring to the interpretation standards adopted by CEMAGREF, it can be concluded that the facilities operate normally and do not show any apparent anomalies at the time of the evaluation (CU> 90\%). In addition, Ammari, O., and Bayali, N., 2016 reported that $10 \%$ of the cases studied at Tadla show poor irrigation uniformity (old installations).

\section{3-1-3 EFFICIENCY OF THE IRRIGATION SYSTEM \\ - EFFICIENCY OF APPLICATION}

According to Kambou D. et al 2014, This indicator is defined as the ratio between the amount of water retained in the root zone (Ws: net dose) and that brought by irrigation (Wd: gross dose) :

$$
\mathrm{Ea}(\%)=(\mathrm{Ws} / \mathrm{Wd}) * 100
$$


According to Hanafi S., 2011, WS is the variation of the water stock in the root profile before and after irrigation, determined by gravimetric method, Ws $\leq$ SWD.

$$
\operatorname{SWD}(\mathbf{m m})=(\mathbf{H c c}-\mathrm{Hpf}) * \mathrm{da} * \mathbf{Z} * \mathbf{1 0}
$$

With: Hcc (Humidity at field capacity in\%), Hpf (Moisture at the point of wilting in\%), da (apparent density in $\mathrm{g} / \mathrm{cm}^{3}, \mathrm{z}$ (depth of soil in $\mathrm{m}$ ). SWD: useful reserve storable in the root zone at the time of irrigation (SWD being 50.72 and $127.62 \mathrm{~mm}$ for $\mathrm{z}=30$ and $60 \mathrm{~cm}$ respectively). Efficiency was calculated assuming percolation losses are negligible (low soil permeability: $0.32 \mathrm{~cm} \mathrm{/} \mathrm{h,} \mathrm{Labomag} \mathrm{2012)} \mathrm{and} \mathrm{have} \mathrm{a} \mathrm{high} \mathrm{water} \mathrm{retention} \mathrm{capacity}$ (Ammari O. and Bayali N., 2016) and also losses due to leakage in the valves are absent. The quantities of water brought in during the irrigations were mastered by reading the meter readings at the beginning and at the end of the irrigation. Thus, the average efficiency obtained is 90 and $91 \%$ respectively for the horizon of the soil $\mathrm{z}=30 \mathrm{~cm}$ and $\mathrm{z}=60 \mathrm{~cm}$ and revolves around an average of $90.5 \%$, which corroborates with the results reported by Elattir, H., 2005 and Ammari, O., and Bayali, N., 2016 (Ea $=90 \%$ and 87\% respectively).

\section{- GLOBAL EFFICIENCY}

The overall efficiency (Eg) of localized irrigation, also referred to as hydraulic efficiency, is defined as the product between the Irrigation Efficiency (Ea) and the Uniformity of Watering Coefficient (CU):

$$
\mathbf{E g}=\mathbf{E a} * \mathbf{C U} ;(\text { Ammari, O., and Bayali, N., 2016). }
$$

The average overall efficiency obtained is $87 \%$ (Min: 82 , max: $89 \%$ and CV: $2.12 \%$ ). In this regard, Ammari O. and Bayali N., 2016 reported that only $60 \%$ of cases had a satisfactory $\mathrm{Eg}(80$ to $86 \%)$.

\section{4- AGRO-ECONOMIC PERFORMANCE}

Data from techno-economic surveys are the basis of the production of various classical agro-economic indicators.

\section{4-1 ANALYSIS AT THE SCALE OF EXPLOITATION}

Harbouze R. et al. 2009, reported the existence of a coherence between the ratio r: product / charges and the efficiency levels of farms in the Gharb region of Morocco. Thus, in our study three classes have been identified: $\mathrm{C}_{1}(\mathrm{r} \leq 2), \mathrm{C}_{2}(2<\mathrm{r}<2.5)$, and $\mathrm{C}_{3}(\mathrm{r} \geq 2.5)$. The analysis of the results of the typology of the farms shows that the highest ratios (class $\mathrm{C}_{3}$ ) are generally recorded by those which consume fewer inputs per hectare (average ratio of 2.8 ) but generate outputs per hectare the highest $(48.000 \mathrm{Dh} / \mathrm{ha})$. These farms, which are considered efficient, consume less water $\left(7.300 \mathrm{~m}^{3} /\right.$ ha) and value it at best at $5 \mathrm{DH} / \mathrm{m}^{3}$ and $6.4 \mathrm{~kg} / \mathrm{m}^{3}$. The farm class $\left(\mathrm{C}_{1}\right)$ had the lowest values of the Outputs / inputs ratio of 1.7, which means that the farmer made a profit equal to $17 / 10$ of the production costs spent against $28 / 10$ for the $\mathrm{C}_{3}$ class. These inefficient farms consume more irrigation water $\left(12.700 \mathrm{~m}^{3} / \mathrm{ha}\right)$ and make little use of it at $2.6 \mathrm{Dh} / \mathrm{m}^{3}$ and $4 \mathrm{Kg} / \mathrm{m}^{3}$.

\section{4-2 ANALYSIS AT THE SCALE OF CULTURE}

By analyzing the scores obtained by speculation, it appears that citrus, sugar beet, fodder and vegetable systems produce the highest added values, with a better valuation of irrigation water $\left(2.3\right.$ at $9 \mathrm{DH} / \mathrm{m}^{3}$ and 5 to $\left.11 \mathrm{Kg} / \mathrm{m}^{3}\right)$. This type of farming is characterized by intensive use of factors of production because of their ability to diversify widely and intensify their production methods. On the other hand, the production systems based on field peas, fodder barley, cereals and beans have little choice of diversification 
and play more on management oriented towards the economy of inputs: management by the charges. These results confirm those obtained by Harbouze R. et al., In 2009 in the Gharb region of Morocco.

\section{5- CHANGES CAUSED BY TRANSITION TO LOCALIZED IRRIGATION}

\section{5-1 EFFECT ON THE CONSUMPTION OF IRRIGATION WATER}

With respect to the combined use of surface and groundwater, the transition to localized irrigation, as reported in Figure 2 below, has resulted in an irrigation water saving of order of $29.52 \%$ by moving from the reference situation to that of after - project. This gain is mainly attributed to a significant decline in the use of groundwater which before approximates $52 \%$ of the quantities of water brought (Hammani A. 2015, reported to TadlaMorocco that private pumped water accounts for $66 \%$ of the perimeter of Beni Moussa groundwater exports), although the use of surface water has increased due to an intensification of cultivation from 107 to $125 \%$ currently. The farmers' declarations go in this direction and confirm the desire to favor the use of currently available surface water at the lowest cost and of the best quality. Fusillier and Saque 2001 quoted by Petitguyot T. 2004 have thus reported situations in which the water consumption per hectare has increased with localized irrigation techniques, due to a poor technical mastery.

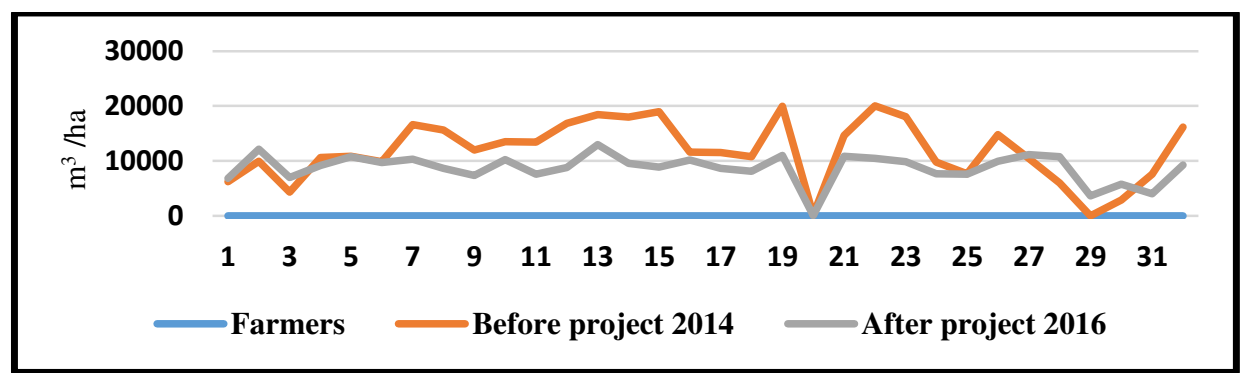

Fig 2: Variation in the combined use of surface water and groundwater Between the reference situation and the post-project situations.

\section{5-2 ENVIRONMENTAL IMPACT}

The environmental parameters data analyzed were retrieved from the water, soil and plant analysis laboratory of the Regional Agricultural Development Office of Tadla.

\section{A- SALINITY OF THE SOIL}

The post-project data for soil salinity measured by horizon were compared to the preproject data as shown in Figure 3 below. 


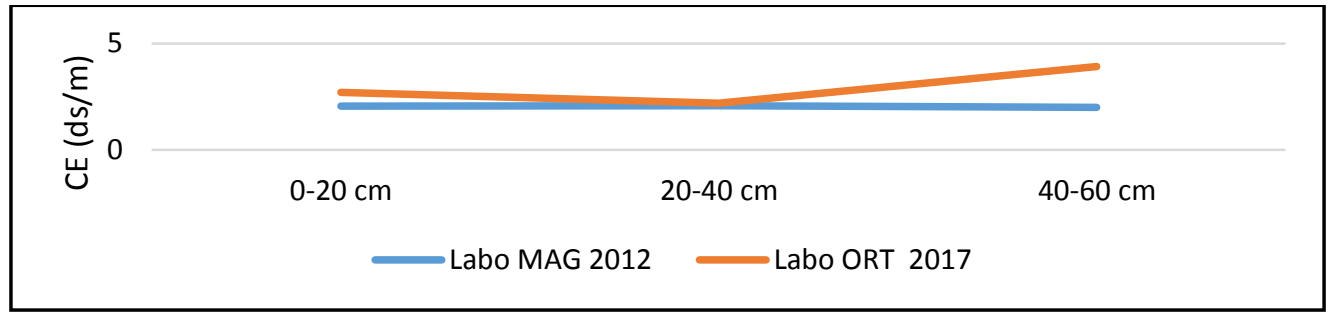

Fig 3: Variation of the electrical conductivity of the soil between the Reference and postproject situation

The analysis of the graph showed an increase in salinity compared to the reference situation 2012 , but to different degrees depending on the horizon of the soil prospected $(+32,+6$ and $+95 \%$ respectively for the horizon $0-20,20-40$ and 40-60 cm. Irrigation and evaporation of water from the soil surface are responsible for the accumulation of salts and the gradual increase of salts in the root zone. intensive agriculture, as in the case of the Tadla perimeter, where the irrigation water is of good quality $(0.51 \mathrm{mS} / \mathrm{cm}$ for surface water and $2 \mathrm{mS} / \mathrm{cm}$ for groundwater), the practice of fertilization remains the major and probable cause of soil salinization. The current values recorded remain below the salinization thresholds advanced by different authors (4.7 dS / m, Noomene H. 2011, up to $8 \mathrm{dS} / \mathrm{m}$, Phocaides A. 2008).

\section{B - QUALITY OF GROUNDWATER}

- The salinity of water: The electrical conductivity of the groundwater recorded an increase between 2014 and 2016 from 2.02 to $2.03 \mathrm{mS} / \mathrm{cm}$, ie $+0.01 \mathrm{mS} / \mathrm{cm}$. This level of salinity remains low to medium and at present does not constitute any constraint in localized irrigation.

- Nitrates: Nitrate ions decreased by $20 \%$ between 2014 and 2016, from 0.46 to 0.37 meq / 1: $22.57 \mathrm{mg} / 1$ thus constituting no constraints at the moment (average quality range of 25 at $50 \mathrm{mg} / \mathrm{l}$, Labomag, 2012)

The effect of soluble salts on soil was approached through:

. Risks related to sodium $\left(\mathbf{S A R}=\left[\mathrm{Na}^{+} *\left(\left(\mathbf{C a}^{2+}+\mathbf{M g}^{2+}\right) / 2\right)^{-1 / 2}\right]\right)$. The content of $\mathrm{Ca}^{2}+$ and $\mathrm{Mg}^{2}+$ ions remains high compared to that of sodium, for the time being eliminating all the risks of permeability by soil sodisation. The current SAR is 2.33 and remains below the threshold of 15 (Phocaides A., 2008).

. Residual sodium carbonate $\left[\mathbf{H C O 3}^{-}-\left(\mathbf{C a}^{2+}+\mathbf{M g}^{2+}\right)\right]$ remains below the standard $1.25 \mathrm{meq} / 1$ (Phocaides A., 2008) from which water becomes dangerous (calcium and magnesium may react with bicarbonate and precipitate in the form of carbonate, the relative concentration of sodium in the exchangeable complex increases and causes the dispersion of the soil).

C- STATIC GROUNDWATER LEVEL: The comparison of the static level of pumping points of underground irrigation water of the studied sample of the preliminary project year 2014 (avg: $12.56 \mathrm{~m}$, Variation Type: 2.94 and CV: 19.44\%) to that of 2016 (avg: $15.15 \mathrm{~m}$, ET: 2.85 and CV: $22.67 \%$ ) showed a drawdown of $2.59 \mathrm{~m}$ due mainly to localized irrigation having limited the infiltration of water towards the aquifer (Hammani 
A. 2015 reported that surface irrigation contributes $71 \%$ to the recharge of the Beni Moussa aquifer, thus constituting the main source of aquifer recharge).

\section{5-3 EFFECT ON AGRO-ECONOMIC PARAMETERS}

The effect of the transition to localized irrigation on agro economic parameters generally led to an improvement in these indices in 2016 for most crops [the case of sugar beet: +142 and $+125 \%$ respectively for Value Added and Valuation of $\mathrm{m}^{3}$ of water] in comparison with 2014. These results are consistent with those obtained by Ammari O. and Bayali N. in 2016 at Tadla- Morocco, having reported a clear superiority of localized irrigation compared to old gravitational technique.

\section{6- CONCLUSIONS AND PRACTICAL RECOMMENDATIONS}

At the end of this investigation, it appears that an irrigation modernization project cannot achieve all the objectives assigned to it without good management being tied up because generally the problems of reconversion are more related to management that at the installation of localized irrigation equipment. The initial objectives of promoting greater sustainability of the use of irrigation water defined in terms of reduction of the use of groundwater and exclusive use of surface water is achieved. However, it is necessary to match development support with localized irrigation safeguards (annual quotas, dissuasive tariffs and optimal irrigation management) for a sober use of factors of production, able to better deal to the risks environmental impacts, shortages, and loss of human capital and invested equipment. At the present time, there are no saline soil surface markings in the area or a problem of destruction of the soil structure by alkalization.

\section{7- ACKNOWLEDGMENTS}

I cannot finish this work without thanking my supervisors Zehor Ait Yacine and Abderrazak El Harti, professors at the FST Beni Mellal for their foresight and the valuable advice that he gave me during this work. My thanks also go to the ORMVAT for providing us with data relating to the quality of the soil and water of the conversion zone. Also my thanks are addressed to the scientific committee of the EDE6 / 2017 BM congress for their framing and their guidelines for the elaboration of the final draft of this article.

\section{BIBLIOGRAPHIC REFERENCES}

1 - Ammari Ouafa et Bayali Najoua, 2016, Etude des pratiques d'irrigation et évaluation des performances de l'irrigation localisée dans le cadre de reconversion collective : Cas du secteur pilote du Tadla. MFE- diplôme d'Ingénieur GR, IAV Hassan II, Rabat, 119p.

2 - Belghiti, M'Hamed, 2012, L'économie et la valorisation de l'eau en irrigation : un impératif pour un développement agricole durable au Maroc, Conférence internationale pour le dessalement et le développement durable, Casablanca.

3 - Benouniche Maya, Marcel Kuper, Ali Hammani. 2014, Mener le goutte-à-goutte à l'économie d'eau: Ambition réaliste ou poursuite d'une chimère? Alternatives rurales (2) Novembre 2014.

4 - Dionnet, M., Kuper, M., Garin, P., Hammani, A., Eliamani, A., Saaf, M., 2006, Accompagner les acteurs dans le changement de leur système. Un jeu de rôles pour des projets collectifs d'irrigation au Tadla, Maroc, Actes du séminaire Wademed, Cahors, France.

5 - El Amri A., Majdoub R., M'Sadak Y, Aouichaoui, 2012. Appréciation expérimentale de l'uniformité de distribution de l'eau dans le périmètre irrigué ZAAFRA II (Tunisie centrale), Larhyss / journal $n^{\circ} 11,11 / 2012$.

6 - El Attir H., 2005. Conduite et pilotage de l'irrigation goutte à goutte en maraichage. Bulletin mensuel $n^{\circ} 124$ d'information et de liaison du PNTTA, transfert de technologie en agriculture. 
7 - Hammani A. 2015.Techniques de gestion des nappes d'eau souterraines en zones interne et externe du réseau hydro-agricole relevant d'un périmètre irrigué. Module de formation ORT/2017.

8 - Kambou D., Xanthoulis D., Donkora K., Ouattara \& Aurore Degré, 2014, Concepts d'efficience et de productivité de l'eau, (synthèse bibliographique), Base En ligne, Volume18, Numéro1, 108-120.

9 - Keller J., Karmeli, D.,1974, Trickle irrigation design parameters, ASAE Transactions, 17(4): 678-68.

10 - Labomag 2012, Caractérisation de référence des paramètres environnementaux au niveau de la zone de reconversion collective à l'irrigation localisée. Rapport fin hiver 2012.

11 - Moghli, E., Benjelloun, T. M., 2000. Valorisation de l'eau d'irrigation par les productions végétales dans les grands périmètres irrigués au Maroc. Hommes Terres et Eaux, Issue 116, pp. 30-38.

12 - Petitguyot T., T. Rieu, A. Chohin-Kuper, R. Doukkali. Modernisation de l'agriculture irriguée et durabilité des ressources en eau dans le périmètre du Tadla au Maroc. Ali Hammani, Marcel Kuper, Abdelhak Debbarh. Séminaire sur la modernisation de l'agriculture irriguée, 2004, Rabat, Morocco. IAV Hassan II, 13 p., 2005. <cirad-00189662>

13- Phocaides A., 2008. Manuel des techniques d'irrigation sous pression. Chapitre 7.14, FAO, Rome, seconde Edition 2008.

14 - Vermeiren L., 1983- Bulletin FAO d'irrigation et de drainage $n^{\circ} 36$ - l'irrigation localisée : calcul, mise en place, exploitation, contrôle du fonctionnement- FAO, Rome, seconde Edition 1983, 220p 